\title{
Strategy of Implementing the Expansion Program of Participation in BPJS Health in Kubu Raya District, West Kalimantan Province, Indonesia
}

\author{
Sri Maryuni Pardi \\ Public Administration Departement,Faculty of Social and Political Science Tanjungpura University, Pontianak, \\ West Kalimantan, Indonesia
}

\begin{abstract}
This research examines a strategy for implementing the expansion program of participation of BPJS Health in Kubu Raya district because there is data and evidence show that the target of membership of the BPJS Health has not yet been determined. The purpose of this research is to seek out appropriate strategies that to achieve the target of BPJS Health participation in 2019. This research uses a qualitative descriptive research method since researchers want to understand the factors that influence on the low achievement of the participation of BPJS Health in Kubu Raya District. The result from the research conducted showed that there are some factors bring to the low achievement of BPJS Health participation targets in Kubu Raya District, they are lack of public knowledge about BPJS Health, lack of socialization about the benefits and importance of BPJS Health participation, and lack of involvement of the Kubu Raya Regional Government in supporting the success of the JKN-KIS program. The researchers recommend a strategy in overcoming this issue is to optimise the socialisation intensely to the public related to the Health BPJS, collaboration with the Regional Government and associated institutions in expanding the membership of BPJS Health.
\end{abstract}

Keywords: Strategy, BPJS Health, Participation, JKN-KIS

DOI: $10.7176 /$ PPAR/9-10-02

Publication date:October $31^{\text {st }} 2019$

\section{Introduction}

National Health Insurance (JKN) is a health insurance program organised by the government. This program is not a new program, but it is a transitional program from the previous government. JKN in Indonesia has been implemented since 2014. Until the 4th year of JKN implementation, it is undeniable found that there are still many shortcomings in its application and still need some efforts to be addressed. JKN is one of the programs that are within the scope of the Social Security Organizing Agency (BPJS) following the Republic of Indonesia Law Number 24 of 2011 concerning the Social Security Organizing Agency. This means that the government and BPJS have been trying to make improvements.

To support these improvements, it is necessary to regularly and continuously monitor and evaluate both internal and external factors to find out the description of the implementation of the ongoing program and to deal with various obstacles, or some difficulties in implementing JKN on the regular and appropriate basis. As the implementer of the JKN program, the Health of Social Security Organizing Agency (BPJS) has a target in developing of participation program, either for individual or business participation as the central government states that by 2019 all citizens must register in the JKN program.

Nationally, according to the JKN membership roadmap at the end of $2017,70 \%$ of the total Indonesian population has been registered as JKN participants. Unfortunately, talking to the condition in some regions, it reveals that only some regions are accounted /have achieved $70 \%$ of the total population registered as JKN participants. The target is indeed still far from the government's expectations. In West Kalimantan, one of the regencies that implement the JKN-KIS Program is Kubu Raya Regency. Kubu Raya Regency reaches 6,985 km2 with a population of 601,356 people (data from SMT I in 2017). Currently, the population of participants in the JKN-KIS program is 330,286 people or around $54.92 \%$ of the total population. The following presents a national roadmap for the participation of BPJS Health, which began in 2014 from the year baseline until 2019. Nationally, the achievement of national participation has reached $70 \%$ of the total population of Indonesia. 


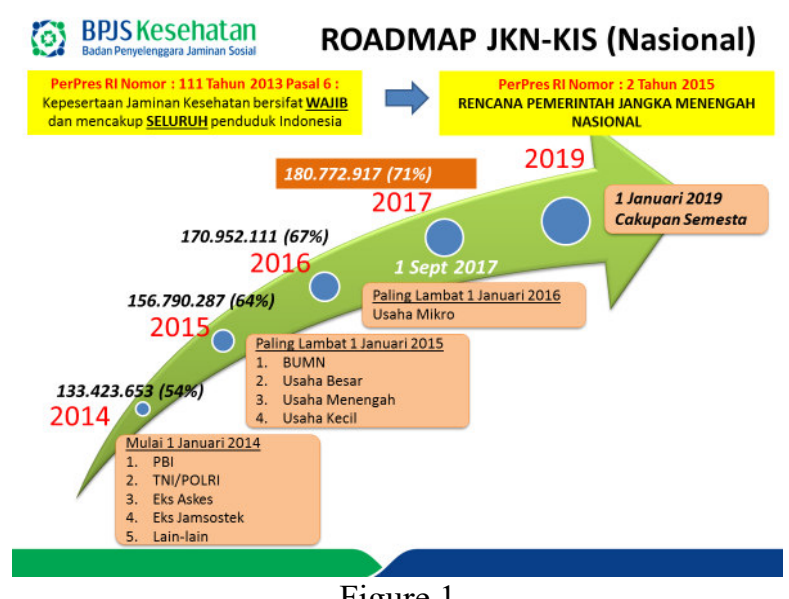

Figure 1

The comparison of the participation target of BPJS Health on a national scale

Table 1.. The comparison of the BPJS

membership target between 10 February 2017 and 1 May 2018:

\begin{tabular}{|c|c|c|c|}
\hline No & Participation types & Per 10 Februari 2017 & Per 1 Mei 2018 \\
\hline 1 & PBI APBN & 92.117 .829 & 92.269 .999 \\
\hline 2 & PBI APBD & 16.016 .383 & 23.135 .458 \\
\hline 3 & PPU-PNS & 13.308239 & 14.088 .029 \\
\hline 4 & PPU-TNI & 1.561 .415 & 1.579 .752 \\
\hline 5 & PPU-POLRI & 1.225 .067 & 1.259 .905 \\
\hline 6 & PPU-BUMN & 1.266 .948 & 1.521 .274 \\
\hline 7 & PPU-BUMD & 162.207 & 180.607 \\
\hline 8 & PPU-SWASTA & 23.607 .441 & 27.918 .849 \\
\hline 9 & PBPU-PEKERJA MANDIRI & 19.998 .541 & 27.648 .348 \\
\hline 10 & BUKAN PEKERJA & 5.060 .573 & 5.059 .553 \\
\hline
\end{tabular}

Source: BPJS Health, 2018.

Based on the data above, it can be seen that the participation of BPJS PPU (wage recipient participants) of BUMN $(1,266,948)$ and BUMD $(162,207)$ is still minimal compared to the Private PPU BPJS which has reached $23,607,441$. Even the independent participants were also higher at 19,998,541. If the data is brought to the regency, participation that has registered as a JKN participant can be seen in the following diagram:

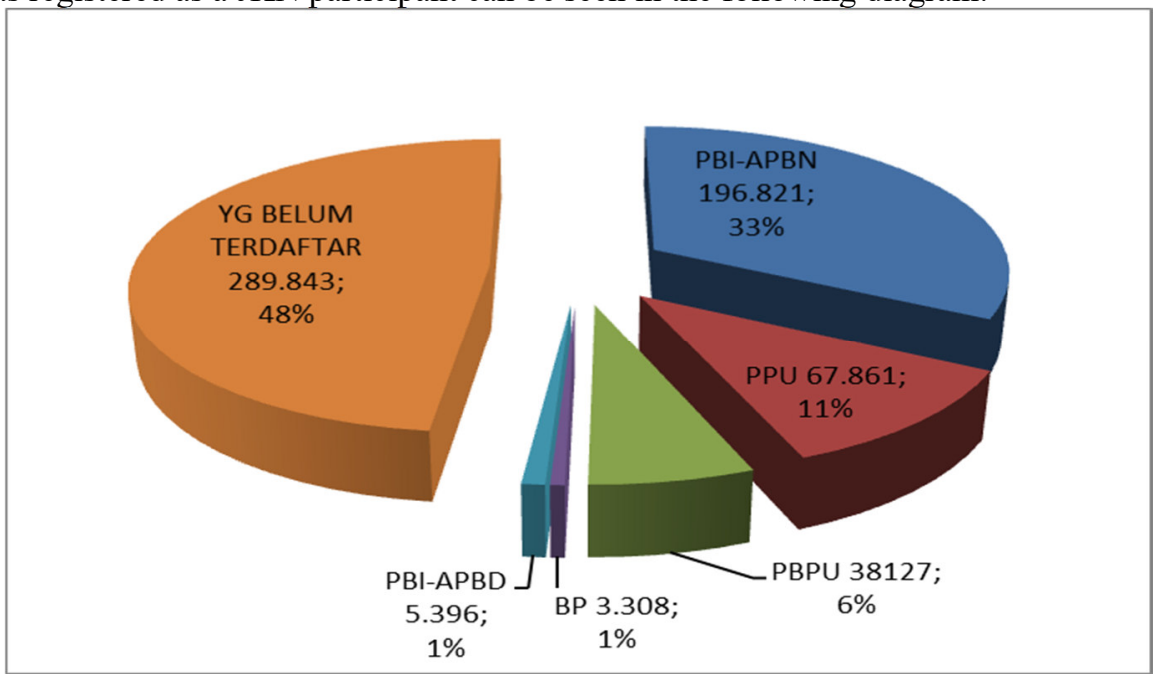

Figure 2. Diagram of the involvement of JKN-KIS in Kubu Raya District (September 20017)

Source: BPJS Health Kubu Raya, 2017

Based on the diagram, there are $48 \%$ of the population who have not yet registered as a member of BPJS Health. Mostly, people who have not registered to become JKN-KIS participants in Kubu Raya Regency is Members of the Business Entity and independent participation. (Source: Information of the Head of BPJS in Kubu 
Raya Regency). This problem is quite interesting to examine that to dig deep about the causes in the implementation of the JKN program. Therefore, researchers are interested in studying the Implementation Strategy for the Extension program for the participations of the BPJS Health in Kubu Raya District, West Kalimantan Province. In implementing this program, the researchers use the legal foundation of Government Regulation (PP) No. 86 of 2013 Article 4 Paragraph (1). It declares that every person, except employer, worker, and recipient of contribution assistance that meets the provisions of the legislation, must register himself and his family members as participants in the BPJS; and provide complete and correct data of himself and his family members to BPJS. Based on the issue above, the research questions could be pursued is "What is the Strategy for Implementation of the JKN Participation Expansion Program in Kubu Raya District?"

\section{Literature Review}

The critical point of policy implementation according to Mazmanian and Sabatier (Widodo, 2010: 87) is to know and understand something as an outcome after a program is declared or formulated. Furthermore, policy implementation is an activity or business that is carried out by implementing policy in the hope that brings to excellent results that are following the goals and objectives of a system (Anggara, 2014: 232).

Also, Van Meter and Van Horn (Abdul Wahab, Solichin, 2008: 65) declared that the implementation of policy is actions taken by individuals, officials, government or private groups that is directed to achieve the goals outlined in policy decisions. Then, it can be concluded that the implementation of policy is an implementation of a resolution in the form of a program or an action to achieve a set of goals.

Van Metter and Van Horn also stated that six variables must be considered that bring to successful of policy implementation, they are:

a. The precise definition of objectives and standards of policy; explaining in details about the goals to be achieved through policies and standards to measure the achievements.

b. Resources (funds or various incentives that would facilitate the effectiveness of implementation).

c. The quality of inter-organisational relations; the success of implementation often requires institutional procedures and mechanisms that allow higher structures to control policy, and then the application will undergo in line with the goals and standards set.

d. Characteristics of institutions/ organisations as executors (including the competence and size of implementing agencies, hierarchical level of control of the lowest implementing unit at the time of implementation, political support from the executive and legislative, and formal and informal linkages with policy-making institutions).

e. The political, social and economic environment (whether financial resources include; how much and how policy influences the ongoing socio-economic conditions; how the response of the public to the system whether it supports for the implementation).

f. Disposition of the responses or attitudes of the implementers (including knowledge and understanding of the content and objectives of the policy, attitudes towards policies and intensity of attitudes).

There are some strategies can be done to achieve the effectiveness of public policy. According to Sabatier and Mazmanian (in Wibawa, 2010), policy implementation is a function of 3 variables, namely (1) the characteristics of the problem, (2) the structure of program management reflected in various types of regulations that operationalise policies and (3) factors outside rules. The implementation of the public policy will be useful if the bureaucracy of implementers adheres to regulations outlined (implementing instructions and technical instructions) with these assumptions, the program objectives and targets must be clear and consistent because they are legal evaluation standard for performing bureaucrats to mobilise resources.

This study uses a theory developed by Daniel Mazmanian and Paul A. Sabatier (in Tachjan, 2006), that policy implementation is a function of three variables: (1) the characteristics of the problem, (2) the program management structure reflected in various types of regulations operationalize policies and (3) factors outside the regulations. An implementation of the policy will be useful if the implementing bureaucracy adheres to what has been outlined in the rules (implementation instructions and technical instructions). With these assumptions, the goals and objectives of the program must be clear and consistent, because these are standard of evaluation legal means for implementing bureaucrats to mobilise resources.

In the first variable (characteristic of the problem), the strategy to increase the success of policy implementation is by understanding:

1. Availability of technology and technical theory

2. The diversity in behaviour of target group

3. Nature of the population

4. The expectation of behaviour change.

Whereas in the second variable (the carrying capacity of the regulation) states that a policy implementation strategy can be carried out by analysing:

1. Clarity/consistency of policy goals and objectives 
2. Adequate causal theory

3. Sufficient financial resources

4. Integration of implementing organisations

5. Implementing discretion

6. Recruitment of executive officers

7. Formal implementing access to other organizations

The third variable outside the policy that can be used to improve the success of policy implementation by understanding:

1. Socio-economic and technological conditions

2. Press attention to policy issues

3. Public support

4. Attitudes and resources of the primary target group

5. Authority support

6. Commitment and leadership capabilities of executive officers

\section{Discussion.}

To increase the participation of BPJS Health in Kubu Raya District, West Kalimantan Province, the West Kalimantan Provincial Health BPJS implements various programs aimed to achieve the BPJS Health membership target in 2019. One of the programs is the BPJS Health Expansion Program in Kubu Raya District, West Kalimantan Province.

This program is implemented by Government Regulation No. Article 86 of Article 86, declared that every person, except the employer, worker, and recipient of contribution assistance under the provisions of legislation must register himself and his family members as participants to the BPJS and provide complete and correct data of them and their family members to BPJS.

To implement PP No. 86 of 2013, the BPJS has a program of membership expansion, which is carried out through the socialisations of the National Health Insurance (JKN) Program in Promoting the Participation of Mandiri BPJS Health Participation in Sungai Belidak Village Sungai Kakap District, Kubu Raya Regency. These socialisations were intended to enable the public to well-informed about BPJS and realise the importance of joining BPJS participants. Besides, interviews were conducted with several community members who took part in the socialization activities to find out whether the community was registered as a BPJS Health participant and to what extent their understanding of BPJS Health.

The BPJS Health Participation Expansion Program is an activity carried out to achieve the specified membership target in 2019. As is known, BPJS has a goal to reach out $95 \%$ registered participants in BPJS, but currently, there are still many people who have not registered yet, both registered from the company where they work or record independently. Therefore, there are several strategies carried out by BPJS Health to increase participation, such as socializations of BPJS Health, establishing cooperation with local governments to expand the scope of the involvement and extending the registration and payment channels for informal sector workers.

Besides, for recruiting formal workers, cooperation is established with BPJS Employment. The registration channel approaches are varied, ranging from make a phone call with the call centre, Mobile JKN application, to the opening of registration facilities in public places such shopping centres, in which registrants only need to carry the form of KTP and ATM card as the requirements.

At present, the number of companies that have registered their employees on the JKN-KIS program is still limited. Therefore, socializations related to this phenomenon will continue in 2018. In addition, BPJS also collaborates with the Attorney General's Office to implement Presidential Instruction No. 8 of 2017 concerning of Optimizing the Implementation of the National Health Insurance Program, where the entire community can understand it. Again, it could encourage the public to register immediately, because besides being mandatory, this can also facilitate the process of implementing the JKN-KIS Program.

For the integration of regional governments with JKN-KIS, currently, there are only around 20.3 million residents from 489 city districts out of a total of 514 districts/cities or 95 per cent of participants. With this fact, it could be said that there are still around 5 per cent of them have not been integrated. Thus the assistance from the Governor, Regent, Mayor is vitally needed to invite the residents to join and become participants.

As a proof of government seriousness in the implementation of the Healthy Indonesia National Card Health Insurance Program (JKN-KIS), President Joko Widodo issued Presidential Instruction Number 8 of 2017 concerning Optimizing the Implementation of the National Health Insurance Program. This instructs 11 state institutions to take steps under their authority to guarantee sustainability and improving the quality of the JKNKIS Program. The 11 leaders of state institutions consist of the Coordinating Minister for Human Development and Culture (PMK), Minister of Health, Minister of Home Affairs, Minister of Social Affairs, Minister of BUMN, Minister of Manpower, Minister of Communication and Information, Attorney General, Director of BPJS Health, Governor, Regent and Mayor. The instruction must be implemented by all interested parties including by BPJS 
Health.

Through the Presidential Instruction, it's the Minister of Health responsibility to evaluate, review and refine regulations related to the health services of the JKN program. In addition, it also improves the fee for health services following quality and cost control principles, accomplishes the referral program and guarantees the availability of medicines and medical devices for JKN participants. Additionally, reviews and improves the system for catastrophic diseases, and guarantees the availability of facilities and infrastructures for health facilities (Faskes) with the regional government, the National Police and the TNI and the private sector.

The Minister of Home Affairs is instructed to improve quality in coaching and supervision of Governors, Regents and Mayors in the implementation of JKN. The Minister must ensure that the head of regional allocates the budget properly to support the implementation of JKN and registers all residents in the JKN program. They should ensure as well as securing Governors, Regents and Mayors to provide facilities and infrastructure for health services and human health resources in every region and provide Number-based population data (NIK) that can be utilised as JKN membership data.

The Minister of Social Affairs is pointed to accelerate verification and validation of data stipulations and changes to improve the quality of data on contribution recipient (PBI). The Minister of BUMN is instructed to ensure that their employee to register and provide complete and correct data for administrators and workers and their family members in the JKN program. At the same time, they should be ensured about the payment of contributions. The Minister of Manpower has a regulation in increasing supervision of employers.

The Minister of Communication and Information is instructed to conduct campaigns and outreach to build public awareness to become JKN participants and facilitating data communication networks for the success of the JKN program information technology (IT) system. The Attorney General is pointed to enforce compliance and law against business entities, BUMN, BUMD, and local governments in optimising the implementation of JKN.

For the Board of Directors of BPJS, the President instructed JKN participants to get access to quality services through the identification of JKN participants and the expansion of cooperation with health facilities that met the requirements and increased collaboration with relevant stakeholders in the context of optimal compliance and JKN program implementation. BPJS was also asked to enhance cooperation with ministries/institutions or other parties in the context of campaigns and public education on the JKN program and conduct regulatory studies and evaluations to ensure the continuity and improvement of the JKN program. Also, doing studies on JKN implementation and providing input for improving JKN program policies, and increasing the amount of collaboration with pharmacies that meet the requirements to ensure the availability of back-referring drugs with clear cooperation criteria and appointment processes according to geographical needs and conditions. BPJS Health Directors are also ordered to provide and provide JKN program data periodically to the Minister of Health to improve quality.

The President also instructs the Regional Government (Governors, Regents and Mayors) to increase their protection and supervision to the Regents and Mayors in implementing JKN; allocating budget for implementing JKN; ensuring the Regents and Mayors allocate similar budgets, and registering all residents as JKN participants; providing facilities and infrastructures, as well as health human resources in the region; ensuring that BUMD records administrators and workers and their family members in the JKN program as well as paying contributions. Also, the Governor is instructed to provide administrative sanctions in the form of not obtaining certain public services to employers who did not comply with the registration and payment of JKN contributions.

The PMK Coordinating Minister is instructed to coordinate, synchronise and control the implementation of the Presidential Instruction; coordinate the assessment of other funding sources for the JKN program; and report the application of Presidential Instruction to the President every six months or at any time needed.

The implementation of the JKN-KIS Program has entered its 5th year in 2018 and on 31 December 2017, the number of JKN-KIS participants has reached $187,982,949$. This means that the number of people who have participated in the JKN-KIS Program is almost $72.9 \%$ of the total population of Indonesia. Hopefully, this evidence could be aligned with the direction of national policies and strategies in the National Medium-Term Development Plan (RPJMN) in 2019, and the target membership will cover a minimum of $95 \%$ by 2019 . However, not only from membership participation aspects, the sustainability of this program is a challenge, and it is expected that 11 state institutions are instructed to strengthen coordination and be able to play a role under its authority. In addition to the part of various stakeholders such as health facilities, professional organisations, related associations, mass media, and the community to provide constructive input and support the implementation of the JKN-KIS Program.

The implementation of public policy or the program is a crucial in realising the mission of federal system or application, where it does not only cover the operationalisation of public policies into bureaucratic mechanisms, but also related to how public policies can be accepted, understood, and get support from the target group. The implementation of the policy must also pay attention to various networks of political, economic and social forces that influence the behaviour of all parties involved. Thus public policies can meet the right targets as the object.

The success of implementing public policy is determined through the process of achievement carried out, as well as the capacity of the implementing agency in managing these various interests. Therefore, several factors 
influence the success of the implementation of public policy or a program, including the Expansion Program of BPJS Health Participation in Kubu Raya District, West Kalimantan Province.

In the research on the implementation of this expansion program, there are three factors from D. Mazmanian and Sabatier to be discussed, namely the characteristics of the problem, the carrying capacity of the regulations, and non-government variables.

\section{Characteristics of the Problem}

The first factor influencing the success of the BPJS Health Program of Expansion in Kubu Raya District, West Kalimantan Province is a characteristic of the problem. This can be interpreted that several obstacles could bring to the success of implementing the program. The barriers are:

a. The behaviour diversity of Target.

The target group of this program are those who have not yet become BPJS Health participants. Since every community that has not been registered has a variety of reasons, the diversity could affect the successful implementation of the BPJS Health Program Expansion Program in Kubu Raya District. As for the various reasons why the community in the region has not been registered, among others, there are still people who do not know about BPJS Health and also consider that BPJS is not a basic need to have.

According to this problem, something that can be done is to intensify the socialisation to the local community so that they know about the Health BPJS and the importance of becoming JKN participants to help the welfare of every community. Also, it is critical that the local government to take a role to urge every community to register as a JKN participant.

b. Technology availability

In implementing the BPJS Health Participation Expansion Program, one of the things that must be considered is to make innovations by adjusting increasingly sophisticated technological developments. Therefore, BPJS has created a Mobile JKN application that can be downloaded by Android users. Mobile $\mathrm{JKN}$ is an application that is accessible to register as a JKN trainee, and to find out information about BPJS Health.

However, at present, there are still many people who do not know if there is a Mobile JKN application that potentially facilitates them to access all information related to BPJS Health such as online membership registration and payment of BPJS Health monthly contributions. Also, another obstacle is that not all local people use Android-based communication tools.

Therefore, it is necessary to conduct a socialisation or approaches to the community to introduce a JKN Mobile application that can make it easier for people to register as JKN participants and access information related to BPJS Health. With this socialisation, people would become well-informed and knowledgeable on how to use and understand the functions of the application.

c. The characteristics of Population

The purpose of the character of the population is that every participant in the socialisation that has been conducted in Sungai Belidak Village, Sungai Kakap Subdistrict, Kubu Raya Regency has a variety of backgrounds. Thus it could influence the success of the implementation of the program. One of the obstacles behind the reason why there are still many people in the village who have not registered to become JKN participants is economic/financial problems. It should be noted, the average profession of the people in Sungai Belidak Village is farmers which they might struggle with the funding, so most of them are objected about the regulation of the policy to register all family members as JKN participants, and also if they were recorded, they are required to pay a compulsory monthly fee.

Although there are some people who had been registered by the Local Government to be the previous participants in the health insurance (now it is integrated into JKN participants) as well as Contributing Aid Recipients (PBI), in this case not all communities received the facility, and when one person was interviewed after socialization completed, he said that he did not know what the criteria would be to obtain the support from the Regional Government, because not all communities in Sungai Belidak Village received supports.

Accordingly, local government should take some initiatives to allocate the regional budget appropriately to help them to register in BPJS, especially for low income family, so that it does not burden the society, because in this case, it is the Regional Government that has such a significant role to help the community in their area. As an illustration in North Kayong, the local government initiatives to allocate some of its regional budgets to register all of its people as BPJS participants, and the monthly fee was borne by the local government.

d. The degree of Expected Behaviour

Regarding the expected degree of behaviour, the BPJS has sought to gain public trust, in which they could voluntarily register themselves as JKN participants. One of the efforts carried out by BPJS was to disseminate information to the target group area, so they knew the importance of becoming JKN 
participants to assist them in the health sector and also as a program aimed at the welfare of the community. Also, when a policy is implemented, one of the expected outcomes is to get the same behaviour degree from one another. In this case, problems usually arise from the community such some complaints about the dissatisfaction of services obtained.

Therefore, BPJS Health tries to minimise the problems that come from various community complaints. These complaints could be directed at the BPJS Health, which is related to administrative issues such as they have paid for the card, but actually they do not get the card, or the problems exist from the Health Facilities (BPJS Working Partners) itself, which relates to the difficulties in delivering the service to the society. If the complaints readdressed to the BPJS, then the problem will be immediately resolved by the BPJS. If the accusations are directed to the health facility, then the BPJS will accommodate and communicate the health facility and promote some helps to overcome the problems to minimalism the complaints and lead to no complaints from the health facility. This strategy aims to prevent the issue of the disadvantaged feeling of such a community, it also to achieve one of the goals of the BPJS Health, in which excellent promoting welfares for the community.

\section{Supports of the regulate.}

Another factor that influences on the success of the implementation of the BPJS Health in Expansion Program is that there is a support capacity of regulations that strengthen the implementation of the program. This program is implemented based on Government Regulation No. Article 86 of Article 86, stated that every person, except the employer, worker, and recipient of contribution assistance that is covered in legislation must register himself and his family members as participants to the BPJS. Also, they are encouraged to provide complete and correct data of himself and his family members to BPJS, as well as Presidential Regulation of the Republic of Indonesia Number 111 of 2013 Article 6 Paragraph 1, declared that the Participation of Health Insurance is compulsory and must cover the entire population of Indonesia.

The carrying capacity of regulations relating to the implementation of this program include:

1. The Clarity of Goals and Objectives,

This program aims to expand the participation of BPJS to achieve the primary target for 2019 and return to its primary objective to provide health insurance to each that will bring to create prosperity for the entire community. The clarity of the goals and objectives set out in the Act, Presidential Regulations, Government Regulations, and regulations related to BPJS, that will facilitate BPJS Health to implement the program and achieve the goals and objectives successfully.

2. Adequate Causal Theory

In addition to supports from regulations that strengthen the implementation of the program, BPJS Health has an activity that called SOP or Business Process (BisPro), which must be done by BPJS employees in providing proper services. With the existence of BisPro, it might direct and guide BPJS to pursue excellent services.

3. Sufficient Financial Resources

Financial is the most crucial feature that influences the success of a program, including the Expansion Program of BPJS Health Participation. BPJS Health obtains the funding resources from participant contributions, investment returns, and allocations of government funding. Thus, these funds will be accommodated to cover the medical expenses of JKN participants.

4. Implementation Organization Integration.

Implementing the BPJS Health Program Expansion Program is the BPJS Health in collaboration with local governments to expand the scope of participation and expand the registration and payment channels for informal sector workers in the area concerned, as well as cooperation with BPJS Employment to recruit formal workers. The registration channel is promoted by a phone call on a call centre or using a feature that is created by BPJS Health, which is the JKN Mobile application.

BPJS Health also cooperates with the Attorney General's Office to carry out Presidential Instruction No. 8 of 2017 concerning on Optimizing the Implementation of the National Health Insurance Program to encourage the public to register immediately to have JKN, as it is a mandatory obligation for the society.

Moreover, the executors of BPJS Health Program Expansion Program Implementers in Kubu Raya Regency are BPJS that collaborate with FISIP UNTAN and Head of Community Health Center along with Sungai Belidak Village Staff, Sungai Kakap Sub-District to socialise the National Health Insurance Program (JKN) in Increasing Participation in BPJS Health Participation.

5. Discretion of program implementer

It becomes the authority of the implemented for a program to succeed, including the commitment of the implementers. The implemented in the dissemination of the National Health Insurance Program (JKN) in Increasing Participation in Mandiri BPJS Health Participation in Sungai Belidak Village, Sungai Kakap Subdistrict, Kubu Raya Regency was the Head of the Health BPJS in Kubu Raya District and the Head 
of the Sungai Belidak Village Health Center.

According to the freedoms/ rights, the BPJS Health of the Kubu Raya District have a right to take action if specific problem is not principally, but if it is not in accordance with BisPro obligation, then it is not permissible, and BPJS in the district must report to the Central Health of BPJS to take followed up action immediately.

6. Formal External Party Access.

This program was implemented in collaboration with other parties that had to do with the expansion of membership, like the community. There is an aspiration box in BPJS Kubu Raya Regency as a facility for society to put suggestions or criticisms from the public for BPJS Health.

\section{Non-Government Variables}

Non-Government variables are other factors that influence on the success of implementing a program besides the main elements (variable characteristics of the problem and the variable carrying capacity of the regulation) which are not related to program implementer. These factors include:

1. Socio-economic and technological conditions

2. Press attention to policy issues

3. Public support

4. Attitudes and resources of the primary target group

5. Authority support

6. Commitment and ability of executive officers

These are some factors that influence the successful implementation of the BPJS Health in Expansion Program in Kubu Raya District, West Kalimantan Province. These factors are used to evaluate the implementation of the program as well as to develop strategies in implementing the program, to produce efficient and effective outcomes in order to achieve the target of BPJS Health participation in 2019.

The solution that might be considered from the issue above to promote intensive socialisations and establish good cooperation with related agencies and oversee these agencies to work effectively based on a regulation that is underlined under Presidential Instruction Regarding the Optimization of the Implementation of the National Health Insurance Program. In addition, it is essential that Regional Government to take active role in society to appeal them about the program, then it could lead to increase public awareness of the importance of having health insurance, increase the number of people to become participants in the National Health Insurance program, raise public awareness or JKN participants to be responsible about their obligations to pay membership fee in the meantime, so it will directly decrease in the number of participants who are in arrears in paying contributions. Importantly, if the community is classified as an impoverished community which means they have the low socialeconomic condition, Regional Government has a responsibility to accommodate them by using existing regional budget to cover the fee for the and an annual membership fee.

\section{Conclusion.}

In order to increase the number of participants of BPJS in Kubu Raya District, West Kalimantan Province, Health BPJS in the province has been implementing the expansion program of participation in Kubu Raya Regency with the aim of reaching the target of BPJS Health participation in 2019, which based on Government Regulation No. Article 86 of Article 86, highlight that every person, besides the employer, worker, and recipient of government's provisions of the legislation, must register themselves and their family members as a participant in BPJS membership, along with providing complete and correct data of them to BPJS.

To implement PP No. 86 of 2013, the BPJS Health has a membership expansion program, which is carried out through the socialisation activities program of the National Health Insurance (JKN) to promote the Participation of BPJS Health Participation in Sungai Belidak Village Sungai Kakap District, Kubu Raya Regency. This activity is intended to enable the public to know about BPJS and realise the benefits of becoming BPJS participants. In addition, interviews were conducted with several communities' members who took part in the socialization activities to find out the percentage of the population that has been registered as a BPJS Health participant and to dig deep about their understanding of BPJS.

In addition, currently, there is a Mobile JKN application that could be inherently accessible for society to register and find out some information relating to Health BPJS. This application can be downloaded for free using an Android system-based Smartphone.

\section{The future research recommendation}

Regarding the current issue of BPJS participation in West Kalimantan that indicate still in low level, it is tremendously pivotal to promote some strategies to achieve the target of BPJS Health participation in 2019 potentially. The Strategies are to collaborate with the local government to conduct socialization and coordination in expanding the scope of program participation held by BPJS Health, as well as intensifying socialization 
regarding BPJS Health, that will lead to increase public awareness about the importance of becoming JKN participants, understanding the social rights and obligations in becoming a member of JKN, in which this will bring to excellent service on health insurance and achieve the welfare of each individual.

Furthermore, it is essential to establish good cooperation among institutions that would succeed the expansion program of BPJS in Kubu Raya District. According to the declaration of Presidential Instruction in Number 8 of 2017 about Optimizing the Implementation of the National Health Insurance Program, as a form of government seriousness in the implementation of the Healthy Indonesia National Card Health Insurance Program (JKN-KIS), thus President Joko Widodo points 11 state institutions to pursue some approaches that is aligned with their authority to seriously guarantee the sustainability and improve the quality of the JKN-KIS Program. These state institutions consist of the Coordinating Minister for Human Development and Culture (PMK), Minister of Health, Minister of Home Affairs, Minister of Social Affairs, Minister of BUMN, Minister of Manpower, Minister of Communication and Information, Attorney General, BPJS Health Directors, Governors, Regents and Mayors. Therefore, if all 11 institutions are able to coordinate well, the target of JKN participation in 2019 will be achieved.

\section{References}

Agustino, Leo. 2012. Dasar-Dasar Kebijakan Publik. Bandung: Alfabeta

African Capacity Building Foundation (ACBF). 2001. Capacity Needs Assessment: A Conceptual Framework, in ACBF Newsletter Vol. 2, p. 9-12

Bungin, Burhan. 2003. Analisis Data Penelitian Kualitatif (Pemahaman Filosofis dan Metodologis ke Arah Penguasaan Model Aplikasi). Jakarta: PT. RAJAGRAFINDO PERSADA

Dunn, William N. 2003. Pengantar Analisis Kebijakan Publik. Yogyakarta: Gadja Mada University Press

Lester, James P, \& Joseph Stewart, Jr. 2000. Public Policy: An Evolutionary Approach. Belmont, CA: Wadsworth Nugroho, Riant. 2006. Kebijakan Publik untuk Negara-Negara Berkembang (Model-model Perumusan Implementasi dan Evaluasi ). Jakarta: PT.Elex Media Komputindo

Rante, Herman \& Dyah Mutiarin. 2015. Persepsi Masyarakat terhadap Layanan Badan Penyelenggara Jaminan Sosial Kesehatan di RSUD Morangan Sleman DIY. Konferensi Nasional ke-2 APPPTM Vol. 1

Subarsono. 2005. Analisis Kebijakan Publik (Konsep, Teori dan Aplikasi). Yogyakarta: Pustaka Pelajar

Soeprapto, Riyadi. 2010. The Capacity Building For Local Government Toward Good Governance. Word Bank Suharto, Edi. 2012. Analisis Kebijakan Publik. Bandung: Alfabeta

Winanrno, Budi. 2002. Teori Proses Kebijakan Publik. Yogyakarta: Media Persindo 